\title{
Freshwater Cladoceran (Cladocera: Branchiopoda) Diversity of Lateritic Rarh Belt of West Bengal, India: A Review
}

\author{
Souraditya Chakraborty ${ }^{1, *}$, Priyanka Halder Mallick ${ }^{2}$ \\ ${ }^{1}$ Department of Zoology, Garhbeta College, West Bengal, India \\ ${ }^{2}$ Department of Zoology, Vidyasagar University, West Bengal, India
}

Received February 6, 2020; Revised March 23, 2020; Accepted March 28, 2020

Copyright $\mathrm{O} 2020$ by authors, all rights reserved. Authors agree that this article remains permanently open access under the terms of the Creative Commons Attribution License 4.0 International License

\begin{abstract}
Zooplankton are microscopic, non-motile, aquatic animals having multifaceted functionalities in aquatic system including trophic dynamics, pollution surveillance, amelioration etc. Systematic enumeration of plankton is of great biological relevance. Geographically, south-western part of West Bengal, including the districts of Murshidabad, Birbhum, Bankura, Puruliya, Purba Bardhaman and Paschim Bardhaman, Purba Medinipur and Paschim Medinipur, is characterised by a red, lateritic soil form and is frequently referred to as the "Rarh belt" or "Rarh Bengal". Due to this unique edaphic factor the biodiversity herein is of special significance. Despite this fact, study on the diversity, abundance and distribution of zooplankton, emphasizing "Cladocera" as a group, in the water bodies of this area, is much unorganized, fragmentary and meagre till date. This review is an attempt to highlight the relevance of Cladocera as an important zooplankton group and provide a systematic catalogue of the Cladocera species recorded in this area till date. As many as 63 species of Cladocera, belonging to 6 families and 24 genera have been recorded from this lateritic red soil Rarh belt. However, it is suspected, the actual species richness of Cladocera in recent times may vary from the number recorded. Thus, there is a need of updation, revalidation and exploration of Cladoceran taxa in this region using modern techniques and current literature.
\end{abstract}

Keywords Cladocera, Diversity, Laterite, Rarh, West Bengal, Wetland, Zooplankton

\section{Introduction}

Zooplankton are microscopic, floating, aquatic organisms that exhibit active swimming movements, can maintain vertical position in water but are unable to navigate and move against appreciable current (Odum 1996). They are one of the most significant biotic components of an aquatic ecosystem affecting most of the functional aspects including food chains, food webs, energy flow and cycling of matter (Murugan et al. 1998). Zooplankton are not only useful as bio indicators, helping in surveillance of environmental quality, but also in ameliorating polluted waters (Dadhick et al. 1999). Comparing number, diversity, size, structure, fecundity, and reproductive strategies of zooplankton in various water bodies help enumerate the nature and extent of pollutant in them (Sarma 1996; Mukhopadhyay et al. 2000). Systematic enumeration of plankton is also of great biological relevance to understand the community dynamics of aquatic ecosystem. Spatial and temporal heterogeneity of zooplankton is a common feature in different aquatic ecosystems and is the result of different interacting physical and biological processes. A number of mutually interacting factors such as change of climatic conditions, physical, chemical parameters affect distribution and diversity of zooplankton communities (Neves et al. 2003). Freshwater zooplankton mainly consists of four major groups, i.e. Protozoa, Rotifera, Cladocera, and Copepoda (Forró et al. 2008).

Geographically, south-western part of West Bengal, comprising the districts of Murshidabad, Birbhum, Bankura, Puruliya, Purba Bardhaman and Paschim Bardhaman, Purba Medinipur and Paschim Medinipur, is characterised by a red lateritic soil form and thus called the Rarh belt or Rarh Bengal (Bagchi and Mukherjee 1983). Due to this unique edaphic feature, the wetlands herein have some inherent distinctive features which make them unique, in terms of physical, chemical parameters and bio-diversity components. Despite this fact, study on the 
diversity, abundance and distribution of zooplankton, emphasizing Cladocera as a group, in the lentic water bodies of this area, is much unorganized, fragmentary and meagre till date.

Such a dearth of systematic information on this natural, nutritive fish feed micro-crustacean fauna is a big obstacle in popularizing their role in fish productivity and wetland conservation in this region.

Thus, the aims of this review are:

i). to reveal the role of Cladoceran zooplankton, in fresh-water ecosystems, fish productivity and other biological purposes,

ii). to enlist the recorded diversity of Cladocerans in southern-western Rarh belt of West Bengal, and

iii). to give recommendations on proper exploration, management and exploitation of this specific group of plankton in future.

This information will summarize the updated information regarding Cladoceran biology in the region for future study.

\section{The Rarh Belt of West Bengal}

Bagchi and Mukherjee (1983), first, geographically recognised the north-southern lateritic belt of West Bengal as Rarh Bengal. In West Bengal, the distribution of laterites and lateritic soils is limited to parts of western fringe, extending in the west-central part of Birbhum, eastern part of Bankura, middle Barddhaman, part of Murshidabad, Paschim Medinipur and eastern parts of Purulia districts, altogether covering an area of approximately $7,700 \mathrm{~km}^{2}$ and lie within the latitudes $22^{\circ} 00^{\prime}$ $\mathrm{N}$ to $24^{\circ} 30^{\prime} \mathrm{N}$ and longitudes $86^{\circ} 45^{\prime} \mathrm{E}$ to $87^{\circ} 50^{\prime} \mathrm{E}$ (Ghosh and Guchhait 2015) (Figure 1). The reddish-brown soil or laterite found here is created as a result of intense weathering of rocks and is made up of mineral assemblages that include iron or aluminum oxides, oxy-hydroxides or hydroxides, kaolinite and quartz. The soil is typically infertile, gravelly and coarse textured, with low humus level and well-drained with low water holding capacity (Ghosh and Guchhait 2015). These typical geomorphic features of the Rarh belt make it an interesting area of study even in context of biological features.

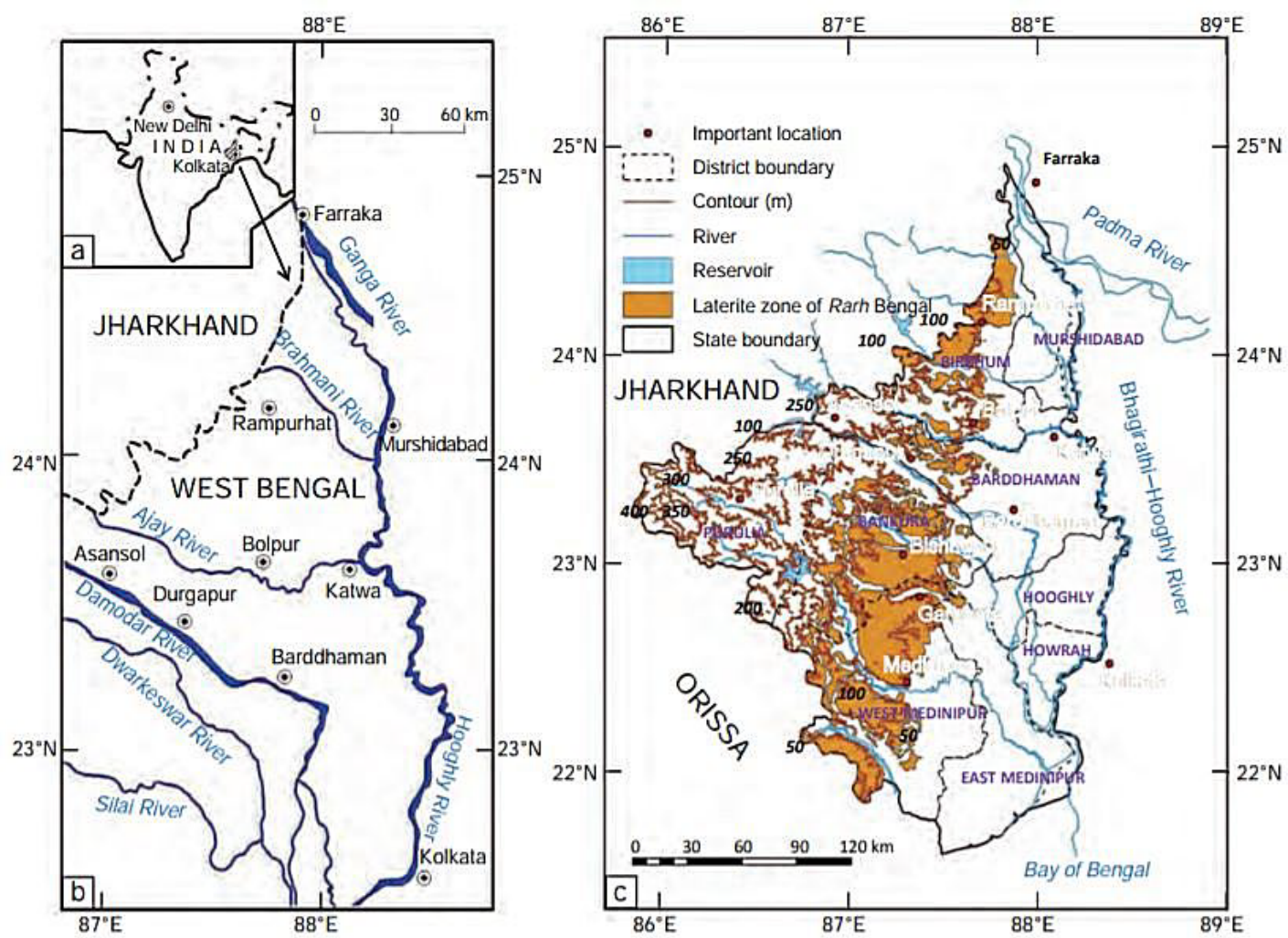

Figure 1. The Rarh belt of West Bengal, India (Ghosh and Guchhait 2015) 
Table 1. District wise impounded fresh water area (including Beel \& Baor) (Handbook of fisheries statistics, W.B., 2015-16)

\begin{tabular}{|c|c|c|c|}
\hline Sl. No. & District & Area (in Ha) & Percentage (\%) \\
\hline 1 & Murshidabad & 28348 & 16.6 \\
\hline 2 & Birbhum & 21377 & 12.5 \\
\hline 3 & Burdwan (Purba and Paschim Burdwan) & 31180 & 18.3 \\
\hline 4 & Bankura & 22655 & 13.3 \\
\hline 5 & Purulia & 18576 & 10.9 \\
\hline 6 & Paschim Medinipur (including Jhargram) & 23150 & 13.6 \\
\hline 7 & Purba Medinipur & 25323 & 14.8 \\
\hline
\end{tabular}

\section{Wetland Profile of Rarh Belt of West Bengal}

Owing to differences in geographical, physical and topographical features, different districts of South Bengal are characterized by a variety of wetlands, both lotic and lentic. In the south-western part, Brahmani, Dwarka, Mayurakshi, Kopai, Ajay, Damodar, Dwarkeswar, Silai, Kansai and Subarnarekha dissect the lateritic Rarh region into patches of forests and habitable areas (Ghosh and Guchhait 2015). In addition, diverse forms of lentic water bodies in the form of dams, bandh, jheel, doba, pukur, dighi, beel, and baor are also spread throughout the area. District wise impounded fresh water habitats of Rarh belt of West Bengal (Handbook of fisheries statistics, W.B., 2015-16) are depicted in the Table 1 .

Among different districts, Burdwan (including both newly formed Purba Bardhaman and Paschim Bardhaman) has the highest impounded fresh water area, followed by Murshidabad. Puruliya has the least amount of freshwater impounded wetlands.

\section{Cladocera - A Unique Zooplankton Group}

The term Cladocera was coined by Latreille (1829) and is derived from two Greek words, 'klados' meaning branch and 'keras' meaning horn, thus, referring to the two branched second antennae which are the chief locomotory structure of these animals. Most of the Cladocerans move through water with a series of hops and jumps and hence called water fleas (Smirnov 1971).

Cladocera is a super-order belonging to the class Branchiopoda of super class Crustacea and are subdivided into four orders-Anomopoda, Ctenopoda, Onychopoda, and Haplopoda (Fryer 1987). Smirnov (1971) numerated a total of eleven Cladoceran families namely Sididae, Daphniidae, Moinidae, Bosminidae, Macrothricidae, Chydoridae, Polyphemidae, Leptodoridae, Podonidae, Holopedidae and Cercopagidae. Freyer's (1987) classification is outlined below:

Superclass: Crustacea (Lamarck 1801)
Class: Branchiopoda (Latreille 1817)

Superorder: Cladocera (Milne-Edwards 1840)

Order- Anomopoda (Sars 1865),

Family: Daphniidae (Straus 1820),

Family: Moinidae (Goulden 1968),

Family: Bosminidae (Baird 1845),

Family: Macrothricidae (Norman and Brady 1867),

Family: Chydoridae (Dybowski and Grochowski 1894)

Order- Ctenopoda (Sars 1865),

Family: Sididae (Baird 1850),

Family: Holopedidae (Sars 1865)

Order- Onychopoda (Sars 1865),

Family: Polyphemidae (Baird 1845)

Family: Podonidae (Mordukhai- Boltovskoi 1968 ),

Family: Cercopagidae (Mordukhai-Boltovskoi 1968).

Order- Haplopoda (Sars 1865)

Family: Leptodoridae (Lilljeborg 1861)

Cladocerans (Crustacea: Branchiopoda), are primarily a monophyletic freshwater zooplankton and form the most useful and nutritive group of crustaceans. (Dumont and Negrea 2002) They are an ancient group of Palaeozoic origin (Forró et al. 2008) and consists mainly micro zooplankton (Dodson and Frey 1991) of size range of 0.2 $6 \mathrm{~mm}$, and up to $18 \mathrm{~mm}$ in a single case of Leptodora kindtii (Focke 1844). These branchiopod crustaceans, inhabit pelagic, littoral, and benthic zones of all lotic and lentic aquatic habitats, viz., lakes, reservoirs, ponds, puddles, swamps, paddy fields, streams and rivers. They are known to be the inhabitants of both the permanent and temporary water bodies (Forró et al. 2008). They are known to be more abundant in temporary water bodies than in permanent freshwater habitats (Hutchinson 1967). Nevertheless, some species can tolerate considerable salinities (eg., some species of the family Ctenopoda, Anomopoda and Onychopoda) (Potts and Durning 1980; Negrea 1983). Cyclical parthenogenesis is the predominant form of reproduction, while, asexual reproduction is occasionally supplemented by sexual reproduction allowing the species to survive tough ambient conditions and allowing far and wide dispersal (Hebert 1997). Most species are filter-feeders and herbivorous while Onychopods and Haplopods are predatory (Fryer 1968). 
Table 2. Significance of Cladocera in aquatic biology

\begin{tabular}{|c|c|c|}
\hline Sl. No. & Feature & Function \\
\hline 1 & Live fish- feed & $\begin{array}{l}\text { Cladocera have always been considered as an important food item of plankton feeding fishes (Scourfield } \\
\text { and Harding 1941). Murugan (1989) has reported presence of high levels of protein, free amino acids, fats } \\
\text { and carbohydrates in Cladocerans like Daphnia carinata, D. longispina, D. magna and D. pulex, making } \\
\text { them highly nutritious and valuable live feed. }\end{array}$ \\
\hline 2 & Trophic dynamics & $\begin{array}{l}\text { As live feed Cladocerans make organic material available to higher trophic levels, in a larger pellet, thus, } \\
\text { saving the foraging energy of their predators (Alikunhi et al. 1955). }\end{array}$ \\
\hline 3 & $\begin{array}{l}\text { Larviculture and } \\
\text { ornamental fish } \\
\text { culture feed }\end{array}$ & $\begin{array}{l}\text { Indulkar and Belsare (2003) mentioned that live Moina sp. is superior to other foods for post-larval stage } \\
\text { of Macrobrachium rosenbergii. Pandey and Yeragi (2000) have also pointed out the importance of } \\
\text { Cladocerans like Moina and Daphnia as live-food organisms in freshwater larviculture and ornamental } \\
\text { fish culture. }\end{array}$ \\
\hline 4 & Bio indicator & $\begin{array}{l}\text { Cladocerans have also been identified as best indicator organisms for assessment of water pollution levels } \\
\text { particularly nutrient enriched eutrophication, resulting from pollution by untreated domestic sewage and } \\
\text { toxicity associated with pesticides (Makrushim, 1976; Gannon and Stemberger, 1978). Cladocera species } \\
\text { are especially responsive to changes in pH, reflecting their sensitivity to acidification and can even react to } \\
\text { very low concentration of contaminants (Zawisza et al. 2016). }\end{array}$ \\
\hline 5 & Test model & $\begin{array}{l}\text { Cladocerans have been used as experimental animals by several biologists in various studies pertaining to } \\
\text { aquatic toxicology (Gannon and Stemberger 1978; and Shiny et al. 2005). Yogendra et al. (2005) } \\
\text { suggested that Daphnia can serve as an ideal test model for bio-monitoring of industrial effluents. }\end{array}$ \\
\hline 6 & $\begin{array}{l}\text { Population control } \\
\text { of mosquito }\end{array}$ & $\begin{array}{l}\text { Cladocerans are also been found to be an efficient agent for mosquito control. They help in reducing larval } \\
\text { mosquito population through suppressing both mosquito oviposition and larval development (Chase et al. } \\
\text { 2003). }\end{array}$ \\
\hline 7 & $\begin{array}{l}\text { Population control } \\
\text { of } \\
\text { micro-organisms }\end{array}$ & $\begin{array}{l}\text { As Cladocerans feed on smaller zooplankton, bacterio-plankton and other phyto plankton (Murugan et al. } \\
\text { 1998) they also regulate the population growth of bacteria, heterotrophic protozoans, microalgae, and even } \\
\text { some rotifer species through trophic relationships and competition (Arnold 1971). }\end{array}$ \\
\hline
\end{tabular}

\section{Relevance of Cladocera as a Group in Aquatic Biology}

Cladocera are a multifaceted group of zooplankton and play substantial role in trophic dynamics, productivity, energy flow, bio monitoring etc. (Forró et al. 2008). Different authors have reported significance of Cladocerans in ecosystem which is listed in Table 2.

\section{Status of Cladoceran Diversity in India}

The currently accepted species richness of Cladocera based on existing descriptions is around 620, however, it is projected that the actual number of species may be 2-4 times higher (Forró et al. 2008). The highest numbers of valid species are reported from Australia, Europe, North America, South America, and the smallest number from Africa and Southern Asia (Korovchinsky 1996). The systematic study on Indian freshwater Cladocera was first initiated by Baird (1860) who published a paper on the Cladocera (Crustacea: Branchiopoda) from India, describing Daphnia newporti (Baird 1860) (Anomopoda: Daphniidae). In a subsequent study, Fernando (1980 a, b) identified the presence of 61 species of Cladocera from India, however, could not find the presence of large Cladocera. Sharma and Michael (1987) noted the presence of 87 species and Michael and Sharma (1988) recorded 93 species in India. Raghunathan (1989), later, recorded 106 species and Sharma (1991) updated the list to 109 species. This number was reconfirmed by Murugan et al. (1998) as well. The Cladoceran diversity till date is relatively more explored only from the states of Meghalaya, Tripura, Assam, Manipur, West Bengal, and to some extent from Bihar (Venkatraman and Das 2000; Sharma and Sharma 2017; Sinha, 2018). Among Indian states, Tamil Nadu has the highest documented Cladocera species followed by Assam (Table 3). Subhash Babu and Nayar (2004) recorded 23 species in Periyar Lake, Kerala. Tiwari et al. (2011) recorded 8 species in Lony dam, Madhya Pradesh. Sharma \& Kotwal (2011) reported 8 species of Cladocera belonging to 6 genera and 4 families in Sungal pond, Jammu and Kashmir. Sharma et al. (2012) reported 54 species of Cladocera belonging to 6 families from 77 different water bodies of south Rajasthan. Venkataraman (1992) recorded 39 species from Keoladeo National Park, Bharatpur. Shah and Pandit (2013) documented 23 species in Wular Lake, Kashmir. Padhye and Dumont (2015) recorded 51 species in Western Ghats of Maharashtra and Goa. Mondal et al. (2013) recorded 6 species of Cladocera in Mirik Lake, Darjeeling. Thakur and Kochar (2017) recorded 9 species from Ludhiana, Punjab. Sharma and Sharma (2014) recorded 55 species belonging to 36 genera from Majuli River Island in Assam. Padhye and Dumont (2015) recorded 51 species of Cladocerans belonging to 6 families from 80 localities in Maharashtra and Goa. Padhye and Victor (2015) also recorded 22 species belonging to 5 families from rock pools of Western Ghats, Maharastra. Sinha (2018) recorded 20 Cladocera species from Arunachal Pradesh. In a recent publication by Zoological Survey of India on faunal diversity of India, Sharma and Sharma (2017) published a comprehensive annotated list of 131 Cladocera species from inland waters of India. 
According to the report, Cladocerans are included in 4 orders, 11 families and 48 genera (Table 4). Chydoridae has been found to be the dominant family followed by
Daphniidae (Table 4). Thus, a comprehensive report on cladoceran diversity, encompassing all Indian states, is still unexplored and wanting.

Table 3. Recorded list of Cladocera species in different states of India

\begin{tabular}{|c|c|c|}
\hline State & Species recorded & Contributor(s) \\
\hline Arunachal Pradesh & 20 & Sinha 2018 \\
\hline Assam & 75 & Sharma and Sharma 2014 \\
\hline Jammu and Kashmir & 23 & Padhye and Dumont 2015 \\
\hline Maharashtra and Goa (Western Ghats) & 51 & Sharma and Sharma 2009, 2010 \\
\hline Manipur & 56 & Sharma and Sharma 1999; Sharma 2008 \\
\hline Meghalaya & 58 & Sharma 2012 \\
\hline Rajasthan & 54 & Raghunathan and Suresh Kumar 2002 \\
\hline Tamil Nadu & 87 & Venkataraman and Das 2000 \\
\hline Tripura & 50 & Sharma 1978; Venkataraman 1999 \\
\hline West Bengal & 56 & \\
\hline
\end{tabular}

Table 4. Taxonomic breakup of Indian freshwater Cladocera (Sharma and Sharma 2017)

\begin{tabular}{|c|c|c|c|}
\hline Family/-Taxon & Species & Genera & Family wise species percentage (\%) \\
\hline \multicolumn{4}{|c|}{ Order Ctenopoda } \\
\hline Family Sididae & 13 & 05 & 9.9 \\
\hline Family Holopedidae & 01 & 01 & 0.8 \\
\hline \multicolumn{4}{|c|}{ Order Anomopoda } \\
\hline Family Daphniidae & & & 19.1 \\
\hline Subfamily Daphniinae & 24 & 03 & \\
\hline Subfamily Scapholeberinae & 01 & 01 & \\
\hline Family Bosminidae & 05 & 02 & 3.8 \\
\hline Family Moinidae & 09 & 02 & 6.9 \\
\hline Family Macrothricidae & 07 & 04 & 5.3 \\
\hline Family Ilyocryptidae & 02 & 01 & 1.5 \\
\hline Family Eurycercidae & 02 & 01 & 1.5 \\
\hline Family Chydoridae & & & 49.6 \\
\hline Subfamily Chydorinae & 27 & 09 & \\
\hline Subfamily Aloninae & 38 & 17 & \\
\hline \multicolumn{4}{|c|}{ Order Onychopoda } \\
\hline Family Polyphemidae & 01 & 01 & 0.8 \\
\hline \multicolumn{4}{|c|}{ Order Haplopoda } \\
\hline Family Leptodoridae & 01 & 01 & 0.8 \\
\hline Total & 131 & 48 & \\
\hline
\end{tabular}




\section{Cladoceran Diversity in Rarh Belt of West Bengal}

The occurrences and distributions of these natural fish-food organisms in the lateritic belt of West Bengal are so far partially documented and too fragmentary. The following studies on cladoceran diversity have been recorded in this area till date: Nandi et al. (2007) in a survey of wetland resources of Puruliya and Bankura district reported the presence of 27 Cladocera from diverse wetland types. In a similar study, Ganesan and Khan (2008) recorded 25 species included in 5 families from Purbasthali, Burdwan. Dutta and Patra (2013) recorded 4 genera of Cladoceran from Jamunabandh at Bishnupur, Bankura.
Majumder et al. (2014) identified 4 genera of Cladoceran in six sampling sites spread around south-western Bankura district. In a similar study, Chatterjee et al. (2014) documented 5 Cladocera species including 3 families from Shahebbandh, a perennial lentic water body from Purulia. Bera et al. (2014) recorded 22 species belonging to 12 genera in Kangsabati reservoir in Bankura district. Mallick and Chakraborty (2015) recorded 7 families including 30 species from few selected wetlands of Paschim Medinipur district. Midya et al. (2018) recorded 10 species from some selected wetlands (in Panskura, Gokulpur, Jakpur) of Purba and Paschim Medinipur districts. The Cladoceran diversity, recorded so far from this region, is listed in Table 5:

Table 5. Recorded species diversity of Cladocera species in the Rarh belt of West Bengal

\begin{tabular}{|c|c|c|}
\hline Family & \multicolumn{2}{|c|}{ Species } \\
\hline \multirow{29}{*}{ Chydoridae } & 1. & Alona affinis (Leydig 1860) \\
\hline & 2. & Alona costata (Sars 1862$) *$ \\
\hline & 3. & Alona davidi (Richard 1895)* Syn. Leberis punctatus (Daday 1898) \\
\hline & 4. & Alona karua (King 1853)* \\
\hline & 5. & Alona pulchella (King 1853) \\
\hline & 6. & Alona rectangular (Sars 1862)* \\
\hline & 7. & Alona quadrangularis (Müller 1776) \\
\hline & 8. & Alona verrucosa (Sars1901)* \\
\hline & & Alonella excise (Fischer 1854) \\
\hline & & Biapertura affinis (Leydig 1860)* \\
\hline & & Biapertura karua (King 1853)* \\
\hline & 12. & Chydorus barroisi (Frey 1862)* \\
\hline & 13. & Chydorus eurynotus (Sars 1901) \\
\hline & 14. & Chydorus herrmanni (Brehm 1934)* \\
\hline & 15. & Chydorus parvus (Daday 1898) \\
\hline & 16. & Chydorus reticulatus (Daday 1898) \\
\hline & & Chydorus sphaericus (Müller 1776) \\
\hline & & Chydorus ventricosus (Daday 1898) \\
\hline & & Dadaya macrops (Daday 1898) \\
\hline & & Ephemeroporus barroisi (Richard 1894) \\
\hline & & Coronatella rectangula (Sars 1862) \\
\hline & & Dunhevedia crassa (King 1853) \\
\hline & & Kurzia latissima (Kurz 1875) \\
\hline & & Kurzia longirostris (Daday 1898) \\
\hline & 25. & Leydigia acanthocercoides (Fischer 1854) \\
\hline & 26. & Picripleuroxus similis (Vavra 1900) \\
\hline & & Pleuroxus aduncus (Jurine 1820) \\
\hline & & Pleuroxus uncinatus (Baird 1850)* \\
\hline & 29. & Pseudochydorus globosus (Baird 1843) \\
\hline
\end{tabular}


Table 5 Continued

\begin{tabular}{|c|c|c|}
\hline \multirow{3}{*}{ Bosminidae } & 30. & Bosmina fatalis (Burckhardt 1924)* \\
\hline & 31. & Bosmina longirostris (Müller 1776) \\
\hline & 32. & Bosminopsis deitersi (Richard 1895) \\
\hline \multirow{17}{*}{ Daphniidae } & 33. & Ceriodaphnia cornuta (Sars 1885) \\
\hline & 34. & Ceriodaphnia lacustris (Birge 1893)* \\
\hline & 35. & Ceriodaphnia regaudi (Richard, 1894)* \\
\hline & 36. & Ceriodaphnia reticulate (Jurine 1820) \\
\hline & 37. & Daphnia ambigua (Scourfield 1947)* \\
\hline & 38. & Daphnia carinata (King 1853) \\
\hline & 39. & Daphnia galeata (Sars 1864)* \\
\hline & 40. & Daphnia longiremis (Sars 1862 )* \\
\hline & 41. & Daphnia lumholtzi (Sars 1885) \\
\hline & 42. & Daphnia magna (Straus 1820) \\
\hline & 43. & Daphnia pulex (Leydig 1860) \\
\hline & 44. & Daphnia retrocurva (Forbes 1882 )* \\
\hline & 45. & Daphnia similis (Claus 1876) \\
\hline & & Scapholeberis kingi (Sars 1888) \\
\hline & 47. & Simocephalus exspinosus (De Geer 1778) \\
\hline & 48. & Simocephalus serrulatus (Koch 1841) \\
\hline & 49. & Simocephalus vetulus (Muller 1776)* \\
\hline \multirow{5}{*}{ Sididae } & 50. & Diaphanosoma excisum (Sars 1885) \\
\hline & 51. & Diaphanosoma sarsi (Richard 1894) \\
\hline & 52. & Diaphanosoma tropicum (Korovchinsky 1998) \\
\hline & 53. & Latonopsis australis (Sars1888) \\
\hline & 54. & Pseudosida bidentata (Herrick 1884)* \\
\hline \multirow{6}{*}{ Macrothricidae } & 55. & Grimaldina brazzai (Richard, 1892) \\
\hline & 56. & Macrothrix brachiate (Jurine 1820)* \\
\hline & 57. & Macrothrix goeldii (Richard 1897)* \\
\hline & 58. & Macrothrix laticornis (Jurine1820) \\
\hline & 59. & Macrothrix spinosa (King 1853) \\
\hline & & Macrothrix triserialis (Brady 1886) \\
\hline \multirow{3}{*}{ Moinidae } & 61. & Moina brachiata (Jurine 1820) \\
\hline & & Moina micrura (Kurz1874) \\
\hline & 63. & Moinodaphnia macleayi (King 1853) \\
\hline
\end{tabular}

* Species not featuring in the updated annotated list of Indian Cladocera published by ZSI (Sharma and Sharma 2017) 


\section{Discussion}

The present review revealed the updated record of 63 species of Cladocera, belonging to 6 families and 24 genera, from the red soil lateritic Rarh belt of West Bengal. This record clearly supersedes the previously documented total 56 Cladoceran (Venkataraman 1999) species from entire West Bengal. This data depicts a moderately high diversity of the taxon in this belt. The record indicates Chydoridae to be the dominant Cladoceran family followed by Daphniidae, while Bosminidae and Moinidae being the least abundant ones. (Table 6).

Table 6. Family wise break up of Cladocera species from the Rarh belt of West Bengal

\begin{tabular}{|c|c|c|c|}
\hline Family & Species & Genera & $\begin{array}{c}\text { Family wise species } \\
\text { percentage (\%) }\end{array}$ \\
\hline Chydoridae & 29 & 12 & 46.0 \\
\hline Bosminidae & 3 & 2 & 4.8 \\
\hline Daphniidae & 17 & 4 & 27.0 \\
\hline Sididae & 5 & 2 & 7.9 \\
\hline Macrothricidae & 6 & 2 & 9.5 \\
\hline Moinidae & 3 & 2 & 4.8 \\
\hline TOTAL & 63 & 24 & \\
\hline
\end{tabular}

Interestingly, 21 species out of 63, recorded in Rarh belt, do not feature in the most recent annotated checklist of "Cladoceran fauna of India", published by Zoological survey of India (Sharma and Sharma 2017). Thus, this raises the ambiguity regarding the validity of the recorded species from this area. This possibility was also remarked by Sharma and Sharma (2017), clearly stating the presence of identification lapses in Indian taxonomic literature including errors such as: 'species inquirendae' (i.e., synonymized new taxa), 'Reports inquirendae' (i.e., dubious reports), 'misidentifications and lapsi' (i.e., misidentifications and lapses). In Cladoceran taxonomy, Alona costata (G.O. Sars 1862), Simocephalus vetulus (O.F. Muller 1776) recorded in various Indian literatures are 'misidentification and lapsi' and should be rechecked with Alona cheni (Sinev 1999) and Simocephalus mixtus (Sars 1903) respectively (Sharma and Sharma, 2017). Same is for Pseudosida bidentata (Herrick, 1884), which has to be rechecked with Pseudosida bidentata (Herrick 1884). Chydorus herrmanni (Brehm 1933), Ceriodaphnia lacustris (Birge 1893), Daphnia ambigua (Scourfield 1947), Daphnia retrocurva (Forbes 1882) have been referred to as 'reports inquirendae', meaning deficiency of proper voucher specimen, illustration, description or specific location (Sharma and Sharma 2017). Chaterjee et al. (2013) mentioned Alona affinis as 'senso lato' referring it to a doubtful species and a part of a species complex. Chaterjee et al. (2013), also suggested that many Oriental species viz., Alona affinis, Leptodora kindtii, Polyphemus pediculus, Diaphanosoma brachyurum, Sida crystallina, Daphnia magna, D. longispina, Ceriodaphnia quadrangula, Macrothrix laticornis, Bosmina longirostris, Eurycercus lamellatus, Alonella exigua, Pleuroxus aduncus, P. trigonellus, Picripleuroxus denticulatus, Graptoleberistes tudinaria are to be accurately revised.

Thus, there is requirement of updation, revalidation and exploration of Cladoceran taxa in this area using modern literatures and techniques. This can unveil the unexplored Cladoceran diversity from this unique lateritic soil belt and also revalidate and justify the recorded diversity.

\section{Recommendations}

Cladocera species recorded in India so far are dubious and need further examination and reconsideration (Chatterjee et al. 2013). Thus, in order to get clear, unambiguous and holistic details of Cladoceran taxa the following recommendations need to be followed:

a. More elaborate sampling should be undergone in this unique habitat type and also in other localities of ecological significance.

b. Voucher or type specimens should be preserved for future reference from each unique habitat.

c. Latest, updated and modern taxonomic keys should be used for unambiguous identification (Chaterjee et al. 2013; Sharma and Sharma 2017).

d. If possible, molecular techniques (including bar coding) system should be applied for verification.

e. Species identified from one area should be compared with similar species identified from other parts of the world for determining phylogenetic relationships.

\section{Conclusions}

Thorough study of available literatures reveals that there is scarcity of any report based exclusively on Cladoceran diversity in Lateritic Rarh Belt of West Bengal, and most information collected here is an ancillary to zooplankton study en masse. Hence, there is a dearth of comprehensive and exclusive studies on Cladoceran fauna of Lateritic Rarh Belt of West Bengal. This inadequacy of information is a handicap in comparing their diversity profile with other regions of the country and the world. Moreover, some recorded data are ambiguous, erroneous and remote, and thus, requires updation, revalidation and exploration using modern literatures and techniques.

Hence, an intensive survey, documentation and monitoring of different Cladocera species in this area is extremely essential to preserve these species and also ecosystem as a whole.

\section{REFERENCES}

[1] Alikunhi K.H, H. Chaudhuri, and V. Ramachandran. On the 
mortality of carp fry in nursery ponds and the role of plankton in their survival and growth. Ind. J. Fish. 2: 257-313. 1955.

[2] Arnold D.E. Ingestion, assimilation survival and reproduction by Daphnia pulex fed seven species of blue green algae. Limnol. Oceanography. 16: 906-921. 1971.

[3] Bagchi K, K. N. Mukherjee. Diagnostic Survey of Rarh Bengal (Part II). University of Calcutta, Calcutta. pp. 23-29. 1983.

[4] Baird W. Description of the two new species of Entomostraceous Crustacea from India. Proc. of the Zoo. Society London. pp. 213-234. 1860.

[5] Bera A, T.K. Dutta, B.C. Patra and U.K. Sar. A study on zooplankton biodiversity of Kangsabati reservoir, W. B., India. International Journal of Development Research. 4(11): 2431-2436. 2014.

[6] Chase J.M. and T.M. Knight. Drought-induced mosquito outbreaks in wetlands. Ecological Letters 6: 1017-1024. 2003.

[7] Chatterjee N, M. Mukherjee, B. Bhattacharjee. Abundance and Diversity of Zooplankton and Its Seasonal Variation in the Water of Sahebbandh, Purulia, India: A Quantitative Study. The International Journal of Science \& Technoledge. 2(12): 22-28. 2014.

[8] Chatterjee T, A.A. Kotov, K. van Damme, S.V.A. Chandrasekhar and S. Padhye. An annotated checklist of the Cladocera (Crustacea: Branchiopoda) from India. Zootaxa 3667(1): 1- 89. 2013. doi: http://dx.doi.org/10.11646/zoota xa.3667.1.1

[9] Dadhick N. and M.M. Saxena Zooplankton as indicators of tropical status of some desert waters near Bikaner. J Environmental Pollution. 6: 251-254. 1999

[10] Dodson S.I. and D.G. Frey. Cladocera and other Branchiopoda. In: Thorp J.H and Covich A.P (ed) Ecology and Classification of North American Freshwater Invertebrates. Academic Press Inc., San Diego, pp. 723-786. 1991.

[11] Dumont H.J. and S. Negrea. Introduction to the class Branchiopoda. In: Guides to the identification of the Microinvertebrates of the Continental Waters of the World. Backhuys Publishers, Netherlands. pp. 323-327. 2002.

[12] Dutta T.K., B.C. Patra. Biodiversity and seasonal abundance of Zooplankton and its relation to physico-chemical parameters of Jamunabundh, Bishnupur, India. International Journal of Scientific and Research Publications. 3(8): 1-7. 2013.

[13] Fernando C.H. A Guide to tropical freshwater zooplankton. In: Identification, Ecology and Impact on Fisheries. Backhuys Publishers, Leiden. pp. 291. 2002.

[14] Fernando C.H. The species and size composition of tropical freshwater zooplankton with special reference to the Oriental region (South East Asia). International Review of Ges. Hydrobiology. 65(3): 411-426. 1980a

[15] Fernando C.H. The freshwater zooplankton of Sri Lanka, with a discussion of tropical freshwater zooplankton composition. International Review of Ges. Hydrobiology. 65: 85-125. 1980 b
[16] Forro. L. Global diversity of Cladocerans (Cladocera; Crustacea) in freshwater. Hydrobiologia. 595: 177-184. 2008. doi:https://doi.org/10.1007/s 10750-007-9013-5

[17] Forro L., N.M. Korovchinsky, A.A. Kotov, A. Petrusek. Global diversity of Cladocerans (Cladocera; Crustacea) in freshwater. Hydrobiologia. 595: 177-184. 2008. doi: https://doi.org/10.1007/s10750-007-9013-5

[18] Fryer G. Evolution and adaptive radiation in the Chydoridae (Crustacea: Cladocera): A study in comparative functional morphology and ecology. Phil. Trans. Roy. Soc. London. 254: pp. 221-385. 1968

[19] Fryer G. A new classification of the Branchiopod Crustacea. Zool. J. Linn. Soc 91: 357-383. 1987.

[20] Ganesan L. and R.A Khan. Studies on the Ecology of Zooplankton in a Floodplain Wetland of West Bengal, India. Proceedings of Taal: The $12^{\text {th }}$ World Lake Conference. pp. 67-73. 2007.

[21] Gannon J.E. and Stemberger R.S. Zooplankton as indicator of water quality. Trans. Amer. Micros. Soc 97: 16-75. 1978.

[22] Ghosh. S. and S.K. Guchhait. Characterization and evolution of primary and secondary laterites in north-western Bengal Basin, West Bengal, India. Journal of Paleogeography. 4(2): 203-230. 2015. doi: https://doi.org/10.3724/SP.J.1261.201 5.00074

[23] Mallick P. H, S.K. Chakraborty. Does Intra-Site Connectivity Influence the Dynamics of Zooplankton Metacommunity in Freshwater Habitats? Turkish Journal of Fisheries and Aquatic Sciences. 15: 661-675. 2015. doi: htt ps://doi.org/10.4194/1303-2712-v15_3_11

[24] Hebert P.D.N.. Genetics of Daphnia. In: Peters RH and Bernardi R de (ed) Daphnia. 'Memorie Dell'. Istituto Italiano Di Idrobiologia, Italy, pp: 439-469. 1987

[25] Hutchinson G.E. A treatise on Limnology: Introduction to the Lake Biology and the Limnoplankton. John Wiley \& Sons, New York 2: 11-15. 1967.

[26] Indulkar S.T and S.G. Belsare Live and inert foods for post-larvae of the giant freshwater prawn Macrobranchium. Israeli J. of Aquaculture Bamidgeh. 55 (4): 45-50. 2003

[27] Korovchinsky N.M. How many species of Cladocera are there? Hydrobiologia. 321: 191-204. 1996.

[28] Latreille M. Crustaces, Arachnideset Partie des Insectes. In: Cuvier, Le Regne Animal. (5) IV. 1829.

[29] Majumder S., A.Patra, T. Dutta, A. Acharyya, R. Goswami. Physico-chemical parameter influenced Zooplankton diversity in some ponds of south western part of Bankura town of WB, India. International Journal of Advanced Research. 2(7): 1146-1157. 2014.

[30] Makrushim A.V. Cladoceran crustaceans as indicators of water pollution. Hydrobiology Journal. 12: 58-60. 1976.

[31] Michael R.G. and B.K. Sharma. Indian Cladocera. Fauna of India and Adjacent Countries, Zoological Survey of India. pp. 262. 1988.

[32] Midya S, S. Bhattacharya, S.S. Islam, R.K. Ganguly and S.K. Chakraborty. Observation on freshwater zooplankton and hydrophytes composition in different wetlands of Paschim 
Medinipur, West Bengal (India). International Journal of Zoology Studies. 3(2): 05-09. 2018. doi: http://dx.doi.org/1 $0.22271 /$ zoology

[33] Mondal D.. Some aspects of hydrobiological study of Mirik lake of the Darjeeling hills. Ph.D Thesis, University of North Bengal, India. Pp. 125. 2009

[34] Mukhopadhyay S.K., A. Chatterjee, R. Gupta, and B. Chattopadhyay. Rotiferan community structure of a tannery effluent stabilisation pond in east Calcutta wetland ecosystem. Chem. Env. Res 9 (1 and 2): 85-91. 2000.

[35] Murugan N. The mass culture of cladoceran Daphnia carinata (King) for use as food in aquaculture. Aqua. Res. Asia., Manang. Techi. Nut.Pro. Asian Seminar Aqua, IFS, Malang, Indonesia. Pp. 190-202. 1989

[36] Murugan N, P. Murugavel and M.S. Koderkar Freshwater Cladocera. Indian Association of Aqua, Biologists (IAAB), Hyderabad. pp. 1-47.1998.

[37] Nandi N.C., K. Venkataraman, S.R. Das and S.K. Das. Wetland faunal resources of West Bengal. Bankura and Puruliya districts. Rec. Zool. Surv. India 107(2); 61-91, 2007.

[38] Negrea S. Crustacea Cladocera. Fauna republic isocialiste Romania. Editura. Acad. Rep. Soc. Romania. 4:1-399. 1983.

[39] Neves I.F., O Recha, K.F Roche., and A.A. Pinto. Zooplankton community structure of two marginal lakes of the river Cuiaba (Mato Grosso, Brazil) with analysis of Rotifera and Cladocera diversity, Braz. J. Biol. 63: 1-20. 2003.

[40] Odum E.P. Fundamentals of Ecology. $3^{\text {rd }}$ edition. Natraj Publishers. New Delhi. pp. 300. 1996.

[41] Padhye S.M and R. Victor. Diversity and distribution of Cladocera (Crustacea: Branchiopoda) in the rock pools of Western Ghats, Maharashtra, India. Int. J. Lim. 51: 315322. 2015. doi: https://doi.org/10.1051/limn/2015029

[42] Padhye S.M. and H.J Dumont. Species richness of Cladoceran (Crustacea: Branchiopoda) in the western ghats of Maharastra, Goa (India) with biogeographical comments. J. Limnol. 74: 182-191. 2015. doi: https://doi.org/10.4081/j1 imnol.2014.1033

[43] Pandey B.D. and S.G. Yeragi. The importance of live feeds in aquatic seed production. Info Jish International. 4: 31-36. 2000 .

[44] Potts W.T.W. and C.T. Durning. Physiology and evolution in the Branchiopods. Comp. Biochem. Physio. 67B: 475484. 1980.

[45] Raghunathan M.B. Indian Cladocera (Crustacea). Indian Review of Life Science. 9: 137-152. 1989.

[46] Raghunathan, M.B and R. Suresh Kumar. Cladocera (Crustacea) of TamilNadu: Checklist and bibliography. Zoos' Print Journal. 17: 959-960. 2002

[47] Resources. Handbook of fisheries statistics 2015-16; 2016. [cited April 2, 2019]. https: //www.wbfisheries.in/files/Stati stical\%20handbook15-16.pdf.

[48] Sarma S.S.S. Some relationships between size structure and fertility of rotifer populations. In Advances in Fish Wildlife
Ecology and Biology, ed. B.L. Kaul. Delhi: Daya Publishing House 1: 37-50. 1996.

[49] Scourfield D.J. and J.P. Harding. A key to the British species of freshwater Cladocera with notes on their ecology. Freshwater Biol. Assoc. Brit. Scientific. Publ 5: 1-50. 1941.

[50] Shah J.A. and A.K. Pandit Diversity and abundance of Cladoceran zooplankton in Wular Lake, Kashmir, Himalaya. Res. J. Environ. Earth Sci 5: 410-417. 2013.

[51] Sharma B.K. Cladocera. In: Animal Resources of India, State of Art, Calcutta: Zoological Survey of India; pp. 205-223.1991.

[52] Sharma B.K. and R.G. Michael. Review of taxonomic studies on freshwater Cladocera from India with remarks of biogeography. Hydrobiologia. 145: 29-33. 1987.

[53] Sharma B.K. and S. Sharma Crustacea: Branchiopoda (Cladocera). In. Chandra K, Gopi KC, Rao DV, Valarmathi $\mathrm{K}$ and Alfred JRB (edn). Current Status on Freshwater Faunal Diversity of India - An Overview. Zoological Survey of India, Kolkata; pp. 199-223. 2017.

[54] Sharma B.K. and S. Sharma. Faunal diversity of Cladocera (Crustacea: Branchiopoda) in wetlands of Majuli (the largest river island), Assam, northeast India. Opuscula Zoologica, Budapest 45(1): 83-94. 2014.

[55] Sharma K.K. and S. Kotwal. Studies on diversity and dynamics of Cladocera in a sub-tropical Sungal pond, Akhnoor (J and K), Bioscan. 6(4): 623-625. 2011.

[56] Sharma S. Notes on some rare and interesting Cladocerans (Crustacea: Branchiopoda) from Meghalaya. Records of Zoological Survey of India. 108:111-122. 2008.

[57] Sharma V, B.K. Verma, R. Sharma, M.S. Sharma., K.S Gaur. A report on the freshwater Cladocera (Crustacea: Branchiopoda) of south Rajasthan (India). Int. J. Env. Sci. 3: 275-296. 2012

[58] Shiny K.J., K.N. Remani, E. Nirmala, T.K. Jalaja and V.K. Sasidharan. Biotreatment of waste water using aquatic invertebrates, Daphnia magna and Paramecium caudatum. Bioresource Technology 96 (1):55-58.2005. doi:https://doi. org/10.1016/j.biortech.2004.01.008

[59] Sinha B. Status of studies on zooplankton fauna of Arunachal Pradesh, India. Journal of Threatened Taxa. 10(11):12552-12560.2018.doi: https://doi.org/10.11609/jott.2998.10.11.

[60] Smirnov N.N. The world Chydorid Fauna (in Russian). USSR Academy of Sciences, Zoological Institute Nova Series, Leningrad. 101: 539. 1971.

[61] Smirnov N.N. and B.V. Timms. A revision of Australian Cladocera (Crustacea). Rec. Austr. Museum. Suppl. 1: 1-132. 1975.

[62] Subhash Babu K.K. and C.K.G. Nayar Cladocera of Periyar Lake and adjacent sites, Thekkady, Kerala. J. Bombay Nat. Hist. Soc. 101: 403-414. 2004.

[63] Thakur A. and Kocher D.K. Diversity and density of Cladoceran population in different types of water bodies of Ludhiana, Punjab (India). Journal of Entomology and Zoology Studies. 5(3): 1568-1572. 2017

[64] Tiwari R.P, C. Sharma and R.B. Tiwari. Studies on 
Cladoceran zooplanktonic population and their correlation coefficient with some physicochemical factors of Lony dam Theonthar, Rewa (M.P.). Int. J. of Pharm. and Life Sci. 2: 1059-1061. 2011.

[65] Venkataraman K. Cladocera of Keoladeo National Park, Bharatpur and its environs. Journal of the Bombay Natural History Society. 89: 17-26. 1992.

[66] Venkataraman K. and S.R. Das Cladocera. In State Fauna Series: Fauna of Tripura. $7^{\text {th }}$ edn. Zoological Survey of India, Calcutta, pp: 277-316. 2000.

[67] Venkataraman K. The freshwater Cladocera (Crustacea:
Branchiopoda). In Fauna of West Bengal. State Fauna Series, $3^{\text {rd }}$ edn. Zoological Survey of India, Calcutta, pp: 251-284. 1999.

[68] Yogendra V, S.G. Ruparelia, M.C. Hargan and P.K. Kulkarni Acute toxicity of the waste water (influent and effluent) of textile mills to water flea. J. Ecobiology. 17(1): 67-73. 2005.

[69] Zawisza E, I. Zawiska, and A.C. Metrio. Cladocera Community Composition as a Function of Physicochemical and Morphological Parameters of Dystrophic Lakes in NE Poland. Wetlands. 36: 1131-1142. 2016. doi: https://doi.or g/10.1007/s 13157-016-0832-x 